\title{
CHARACTERISATION OF PATHOGENIC SPECIES OF CANDIDA BY GAS CHROMATOGRAPHY: PRELIMINARY FINDINGS
}

\author{
P. M. Lategan, S. C. Erasmus and J. C. du Preez \\ Department of Microbiology, University of the Orange Free State, Bloemfontein, 9300, Republic \\ of South Africa
}

\begin{abstract}
SUmmaRY. The volatile substances produced and utilised by some species of Candida isolated from man, were determined in two cultural conditions by gas chromatography. It was possible to characterise Candida krusei, C. parapsilosis, C. tropicalis, C. albicans and C. guilliermondii, but more species and isolates would have to be studied for conclusive results.
\end{abstract}

\section{INTRODUCTION}

The concept of identification of bacteria, especially anaerobes, by the detection of their metabolites by gas chromatography, has been described by several authors, e.g., MacGee (1968), Mitruka and Alexander (1968), Rogosa and Love (1968), Henkel (1971), Carlsson (1973), Wade and Mandle (1974), Mayhew and Gorbach (1977), van Assche (1978), Lategan, du Preez and Potgieter (1978). Papers on the classification and characterisation of bacteria by gas chromatography have been published, but we have been unable to find references, in this connection, to the pathogenic yeasts. This report describes the metabolites produced by Candida in screw-capped bottles and in shake-flask cultures and detected by a gas-chromatographic procedure that allowed the direct injection of culture supernates (fluids).

\section{MATERIALS AND METHODS}

Strains of Candida. Two isolates of each of the following yeasts, from human clinical specimens, were obtained from the Department of Medical Microbiology, University of Pretoria: C. albicans (one each of type A and type B), C. tropicalis, C. krusei, C. guilliermondii and C. parapsilosis.

Culture media. The organisms were cultivated in duplicate in Sabouraud's broth, containing Peptone (E. Merck, Darmstadt, W. Germany) $10 \mathrm{~g}$, D-glucose anhydrous (E. Merck) $20 \mathrm{~g}$, distilled water $1 \mathrm{~L}$.

Ten $\mathrm{ml}$ of the medium in $25-\mathrm{ml} \mathrm{screw-capped} \mathrm{bottles} \mathrm{and} 50 \mathrm{ml}$ in $250-\mathrm{ml}$ Erlenmeyer flasks with cotton plugs were inoculated with $0.1 \mathrm{ml}$ and $0.5 \mathrm{ml}$ respectively of 24 -h culture and incubated at $30^{\circ} \mathrm{C}$ for $48 \mathrm{~h}$ before analysis by gas chromatography. Uninoculated media were incubated as controls.

Gas-chromatographic analyses. After incubation the cells were centrifuged at $3000 \mathrm{~g}$ for 30 min, and $1 \mathrm{ml}$ of $20 \%(\mathrm{v} / \mathrm{v})$ formic acid (E. Merck) was added to $4 \mathrm{ml}$ of supernate to minimise ghosting (du Preez and Lategan 1976, 1978). $\alpha$-Picoline (2-methylpyridine) (British Drug Houses, Faney Road, Poole, Dorset) was added as an internal standard. A Varian 800 autosampler (Varian Inc., Palo Alto, Calif, USA) was used for the on-column injection of 3- $\mu$ l sample volumes into a 5830A gas chromatograph (Hewlett Packard Avondale, Penn, USA) with an FID detector and electronic integrator. Between each determination the column was purged twice with $3-\mu$ l injections of $20 \%$ formic acid.

Porapak N (Waters Assoc., Mass, USA) packed in a $1.5 \times 4-\mathrm{mm}$ internal diameter glass column was used.

Received 18 Jul. 1980; revised version accepted 9 Sep. 1980. 
Operating temperatures were: column $185^{\circ} \mathrm{C}$, inlet $220^{\circ} \mathrm{C}$, detector (FID) $240^{\circ} \mathrm{C}$. The

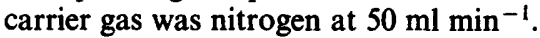

Some of the metabolites were identified by retention times on the column by comparison with those of the pure chemicals, and confirmed on a column of Carbowax $20 \mathrm{M}$ (Analabs Inc., North Haven, Conn, USA). The peak areas of the control media were subtracted from the values obtained in the culture media.

The analyses showed that the Sabouraud's medium used for cultivation contained acetic acid, propionic acid, valeric acid, isovaleric acid and two unidentified volatile substances with retention times of $6.83 \mathrm{~min}$ and $20.8 \mathrm{~min}$ respectively. A peak with a retention time of $4.5 \mathrm{~min}$ appeared and valeric acid disappeared in the shake flasks containing the uninoculated medium. Some of these compounds were utilised by the yeast and the utilisation was expressed as a percentage of the original concentration in the medium. Acetic acid and isovaleric acid were also produced by some of the candida species and the peak areas, after subtraction of the peak areas in the control medium, are presented.

All data were corrected according to the mean of the values obtained with the internal standard.

\section{RESUlTS AND DISCUSSION}

The results obtained with the organisms in closed bottles are presented in table I and for the shake cultures in table II.

Ethanol was produced by all the species and, as expected, more was produced in the closed bottles. $C$. krusei was easily recognised by the production of an unidentified metabolite with a retention time of 3.77 min in both conditions. It was also the only organism that produced acetic acid in aerobic conditions. C. parapsilosis was the only organism that produced acetic acid in the closed bottles. C. tropicalis utilised less isovaleric acid than the other species (table I). The two remaining species, $C$. albicans and $C$. guilliermondii, could be separated because in the capped bottles the former produced less ethanol (table I) and in the shake flasks approximately three times more isovaleric acid (table II).

Acetoin was produced by all the candida species but more was produced in the aerobic conditions. This is in accordance with our experience with genera of the Enterobacteriaceae

TABLE I

Production of metabolites and percentage removal of volatile substances from the medium by candida species in screw-capped bottles

\begin{tabular}{|c|c|c|c|c|c|c|c|c|c|}
\hline \multirow[b]{2}{*}{ Species } & \multicolumn{9}{|c|}{ Production ( + values $*$ ) or removal $(-$ values $\dagger)$ of indicated substance at retention time $(\mathrm{min})$ of } \\
\hline & $\begin{array}{c}1 \cdot 23 \\
\text { Ethanol }\end{array}$ & $\begin{array}{c}3 \cdot 77 \\
\text { Unident- } \\
\text { ified }\end{array}$ & $\begin{array}{c}5 \cdot 2 \\
\text { Acetic } \\
\text { acid }\end{array}$ & $\begin{array}{l}6.83 \\
\text { Unident- } \\
\text { ified }\end{array}$ & $\begin{array}{c}8 \cdot 59 \\
\text { Propionic } \\
\text { acid }\end{array}$ & $\begin{array}{c}13 \cdot 15 \\
\text { Acetoin }\end{array}$ & $\begin{array}{l}20 \cdot 8 \\
\text { Unident- } \\
\text { ified }\end{array}$ & $\begin{array}{c}27 \cdot 5 \\
\text { Isovaleric } \\
\text { acid }\end{array}$ & $\begin{array}{c}33.0 \\
\text { Valeric } \\
\text { acid }\end{array}$ \\
\hline $\begin{array}{l}\text { C. albicans type } \mathrm{A} \\
\text { C. albicans type } \mathrm{B}\end{array}$ & $\begin{array}{l}+4550 \\
+3697\end{array}$ & $\cdots$ & $\begin{array}{l}-72 \% \\
-81 \%\end{array}$ & $\begin{array}{l}-50 \% \\
-60 \%\end{array}$ & $\begin{array}{l}-85 \% \\
-79 \%\end{array}$ & $\begin{array}{l}+17 \\
+13\end{array}$ & $\begin{array}{l}-84 \% \\
-82 \%\end{array}$ & $\begin{array}{l}-100 \% \\
-100 \%\end{array}$ & $\begin{array}{l}-88 \% \\
-69 \%\end{array}$ \\
\hline $\begin{array}{l}\text { C. tropicalis } \\
\text { C. tropicalis }\end{array}$ & $\begin{array}{l}+4281 \\
+6438\end{array}$ & $\begin{array}{l}\ldots \\
\ldots\end{array}$ & $\begin{array}{l}-76 \% \\
-83 \%\end{array}$ & $\begin{array}{l}-90 \% \\
-90 \%\end{array}$ & $\begin{array}{l}-100 \% \\
-100 \%\end{array}$ & $\begin{array}{l}+32 \\
+22\end{array}$ & $\begin{array}{l}-100 \% \\
-100 \%\end{array}$ & $\begin{array}{l}-2.5 \% \\
-8 \%\end{array}$ & $\begin{array}{l}-100 \% \\
-100 \%\end{array}$ \\
\hline $\begin{array}{l}\text { C. krusei } \\
\text { C. krusei }\end{array}$ & $\begin{array}{l}+2145 \\
+1779\end{array}$ & $\begin{array}{l}+28 \\
+25\end{array}$ & $\begin{array}{l}-40 \% \\
-52 \%\end{array}$ & $\begin{array}{l}-17 \% \\
-10 \%\end{array}$ & $\begin{array}{l}-44 \% \\
-43 \%\end{array}$ & $\begin{array}{l}+16 \\
+13\end{array}$ & $\begin{array}{l}-50 \% \\
-42 \%\end{array}$ & $\begin{array}{l}-42 \% \\
-58 \%\end{array}$ & $\begin{array}{l}-63 \% \\
-32 \%\end{array}$ \\
\hline $\begin{array}{l}\text { C. guilliermondii } \\
\text { C. guilliermondii }\end{array}$ & $\begin{array}{l}+6294 \\
+6019\end{array}$ & $\begin{array}{l}\cdots \\
\ldots\end{array}$ & $\begin{array}{l}-78 \% \\
-86 \%\end{array}$ & $\begin{array}{l}-91 \% \\
-92 \%\end{array}$ & $\begin{array}{l}-100 \% \\
-100 \%\end{array}$ & $\begin{array}{l}+18 \\
+20\end{array}$ & $\begin{array}{r}-100 \% \\
-95 \%\end{array}$ & $\begin{array}{l}-58 \% \\
-25 \%\end{array}$ & $\begin{array}{l}-100 \% \\
-100 \%\end{array}$ \\
\hline $\begin{array}{l}\text { C. parapsilosis } \\
\text { C. parapsilosis }\end{array}$ & $\begin{array}{l}+2124 \\
+2418\end{array}$ & $\begin{array}{l}\ldots \\
\cdots\end{array}$ & $\begin{array}{l}+24 \\
+44\end{array}$ & $\begin{array}{l}-44 \% \\
-18 \%\end{array}$ & $\begin{array}{l}-100 \% \\
-100 \%\end{array}$ & $\begin{array}{l}+15 \\
+18\end{array}$ & $\begin{array}{l}-100 \% \\
-100 \%\end{array}$ & $\begin{array}{l}-100 \% \\
-100 \%\end{array}$ & $\begin{array}{l}-100 \% \\
-100 \%\end{array}$ \\
\hline
\end{tabular}

* Peak area $\left(10^{-3}\right)$.

$\dagger$ Percentage of original concentration in culture medium. 
TABLE II

Production of metabolites and percentage removal of volatile substances from the medium by Candida species in shake flasks

\begin{tabular}{|c|c|c|c|c|c|c|c|c|c|}
\hline \multirow[b]{2}{*}{ Species } & \multicolumn{9}{|c|}{ Production (+ values*) or removal ( - values $\dagger$ ) of indicated substance at retention time (min) of } \\
\hline & $\begin{array}{c}1 \cdot 23 \\
\text { Ethanol }\end{array}$ & $\begin{array}{c}3 \cdot 77 \\
\text { Unident- } \\
\text { ified }\end{array}$ & $\begin{array}{l}4.5 \\
\text { Unident- } \\
\text { ified }\end{array}$ & $\begin{array}{l}5 \cdot 2 \\
\text { Acetic } \\
\text { acid }\end{array}$ & $\begin{array}{l}6 \cdot 83 \\
\text { Unident- } \\
\text { ified }\end{array}$ & $\begin{array}{l}8.59 \\
\text { Propionic } \\
\text { acid }\end{array}$ & $\begin{array}{l}13 \cdot 15 \\
\text { Acetoin }\end{array}$ & $\begin{array}{l}20 \cdot 8 \\
\text { Unident- } \\
\text { ified }\end{array}$ & $\begin{array}{l}27 \cdot 5 \\
\text { Isovaleric } \\
\text { acid }\end{array}$ \\
\hline $\begin{array}{l}\text { C. albicans type A } \\
\text { C. albicans type B }\end{array}$ & $\begin{aligned} & +32 \cdot 5 \\
+ & 1052\end{aligned}$ & $\begin{array}{l}\ldots \\
\ldots\end{array}$ & $\begin{array}{l}-100 \% \\
-100 \%\end{array}$ & $\begin{array}{l}-61 \cdot 5 \% \\
-57.5 \%\end{array}$ & $\begin{array}{l}-80 \% \\
-99 \%\end{array}$ & $\begin{array}{l}-100 \% \\
-100 \%\end{array}$ & $\begin{array}{l}+106 \\
+212 \cdot 5 \%\end{array}$ & $\begin{array}{l}-100 \% \\
-92 \%\end{array}$ & $\begin{array}{l}+66 \\
+84\end{array}$ \\
\hline $\begin{array}{l}\text { C. tropicalis } \\
\text { C. tropicalis }\end{array}$ & $\begin{array}{l}+464 \\
+354\end{array}$ & $\begin{array}{l}\ldots \\
\ldots\end{array}$ & $\begin{array}{l}-100 \% \\
-100 \%\end{array}$ & $\begin{array}{l}-14 \% \\
-52 \%\end{array}$ & $\begin{array}{l}-94 \% \\
-93 \%\end{array}$ & $\begin{array}{l}-91 \% \\
-91 \%\end{array}$ & $\begin{array}{l}+171.5 \\
+174.5\end{array}$ & $\begin{array}{l}-100 \% \\
-100 \%\end{array}$ & $\begin{array}{l}+73 \\
+72\end{array}$ \\
\hline $\begin{array}{l}\text { C. krusei } \\
\text { C. krusei }\end{array}$ & $\begin{array}{l}+785 \cdot 5 \\
+340\end{array}$ & $\begin{array}{l}+49 \\
+40\end{array}$ & $\begin{array}{l}-100 \% \\
-100 \%\end{array}$ & $\begin{array}{l}+68 \\
+54 \cdot 4\end{array}$ & $\begin{array}{l}-81 \% \\
-83 \%\end{array}$ & $\begin{array}{l}-100 \% \\
-100 \%\end{array}$ & $\begin{array}{l}+104 \\
+101\end{array}$ & $\begin{array}{l}-100 \% \\
-100 \%\end{array}$ & $\begin{array}{l}+\mathrm{V} \\
+\mathrm{V}\end{array}$ \\
\hline $\begin{array}{l}\text { C. guilliermondii } \\
\text { C. guilliermondii }\end{array}$ & $\begin{array}{l}+507 \\
+566.5\end{array}$ & $\begin{array}{l}\cdots \\
\cdots\end{array}$ & $\begin{array}{l}-100 \% \\
-100 \%\end{array}$ & $\begin{array}{r}-0 \% \\
-19 \%\end{array}$ & $\begin{array}{l}-92 \% \\
-93 \%\end{array}$ & $\begin{array}{l}-89 \% \\
-88 \%\end{array}$ & $\begin{array}{l}+151 \\
+148\end{array}$ & $\begin{array}{l}-97 \% \\
-95 \%\end{array}$ & $\begin{array}{l}+23 \\
+17\end{array}$ \\
\hline $\begin{array}{l}\text { C. parapsilosis } \\
\text { C. parapsilosis }\end{array}$ & $\begin{array}{r}+1156 \\
+651\end{array}$ & $\begin{array}{l}\ldots \\
\ldots\end{array}$ & $\begin{array}{l}-100 \% \\
-100 \%\end{array}$ & $\begin{array}{l}-21 \cdot 4 \% \\
-42 \cdot 9 \%\end{array}$ & $\begin{array}{l}-78 \cdot 1 \% \\
-78 \cdot 5 \%\end{array}$ & $\begin{array}{l}-100 \% \\
-100 \%\end{array}$ & $\begin{array}{l}+92 \\
+80\end{array}$ & $\begin{array}{l}-100 \% \\
-100 \%\end{array}$ & $\begin{array}{l}+64 \\
+49\end{array}$ \\
\hline
\end{tabular}

$\mathrm{V}=$ variable

$*$ and + As in table I.

(van Vuuren, Lategan, Erasmus, unpublished data) and Staphylococcus aureus (Lategan et al., 1978).

In these experiments it was possible to characterise C. krusei, C.parapsilosis and C. tropicalis, C. albicans and C. guilliermondii. For a conclusive indication on the value of gas chromatography in identifying pathogenic yeasts, a comprehensive study on more species and more representative strains is necessary. The present study suggests that this deserves investigation.

We thank Mr S. Lategan, Department of Medical Microbiology, University of Pretoria, for the isolation and identification of the cultures used in the study.

\section{REFERENCES}

CARLsSON, J. 1973. Simplified gas chromatographic procedure for identification of bacterial metabolic products. Appl. Microbiol., 25, 287.

Du Preez, J. C. and Lategan, P. M. 1976. Gas chromatographic determination of $\mathrm{C}_{2}-\mathrm{C}_{5}$ fatty acids in aqueous media with a Porapak N column. J. Chromatogr., 124, 63.

Du PreEZ, J. C. AND LATEGAN, P. M. 1978. Gas chromatographic analysis of $\mathrm{C}_{2}-\mathrm{C}_{5}$ fatty acids in aqueous media using Carbopack B-Carbowax 20M-phosphoric acid. J. Chromatogr., 150, 259.

Henkel, H. G. 1971. Gas chromatographic analysis of low boiling fatty acids in biological media. J. Chromatogr., 58, 201.

Lategan, P. M., DU Preez, J. C. And Potgieter, H. J. 1978. Preliminary findings on the characterization of bacteria causing mastitis by gas chromatography. Br.vet.J., 134, 342 .

MACGEE, J. 1968. Characterization of mammalian tissues and microorganisms by gas chromatography. J. gas Chromatogr., 6, 48.

MAYHEW, J. W. AND GORBACH, S. L. 1977. Internal standards for gas chromatographic analysis of metabolic end products from anaerobic bacteria. Appl. envir. Microbiol., 33, 1002.

MitruKa, B. M. AND AleXANDER, M. 1968. Rapid and sensitive detection of bacteria by gas chromatography. Appl. Microbiol., 16, 636.

RogosA, M. AND Love, L. L. 1968. Direct quantitative gas chromatographic separation of 
$\mathrm{C}_{2}-\mathrm{C}_{5}$ fatty acids methanol and ethyl alcohol in aqueous microbial fermentation media. Appl. Microbiol., 16, 285.

VAN ASSCHE, P. F. D. 1978. Differentiation of Bacteriodes fragilis species by gas chromatographic detection of phenylacetic acid. J. clin. Microbiol., 8, 614.

WADE, T. J. AND MANDLE, R. J. 1974. New gas chromotographic characterization procedure: preliminary studies on some Pseudomonas species. Appl. Microbiol., 27, 303. 